\title{
Surgical Treatment of Cervical Spine Fibrous Dysplasia: Case Report and Literature Review
}

\author{
JORGE H. NUÑEZ, MD, ${ }^{1,4}$ PILAR GONZÁLEZ-TARTIÈRE, MD,${ }^{2}$ FRANK ERIMEIKU, MD,${ }^{1}$ \\ ANA GARCÍA DE FRUTOS, MD ${ }^{3}$ MANUEL RAMÍREZ, MD ${ }^{3}$ \\ ${ }^{1}$ Department of Orthopedic Surgery and Traumatology, University Hospital of Vall d'Hebron, Universitat Autónoma de Barcelona, Barcelona, Spain, ${ }^{2}$ Vall d'Hebron \\ Research Institut Barcelona, Barcelona, Spain, ${ }^{3}$ Spine Unit, University Hospital of Vall d'Hebron, Barcelona, Spain ${ }^{4}$ Spine Unit, Department of Orthopedic Surgery, \\ University Hospital of Mutua Terrasa, Barcelona, Spain
}

\begin{abstract}
Background: Fibrous dysplasia (FD) is an uncommon benign intramedullary fibro-osseous lesion. Cervical spine compromise is rare with only cases reported. Currently, the natural history of cervical FD is poorly understood, and its treatment remains controversial.

Methods: A review of the literature was performed to analyze and discuss the management of cervical FD through a case report and literature review.

Results: Cervical FD is a rare benign pathology. Clinical presentation is usually casual or only clinical pain. Computed tomography (CT)-guided percutaneous biopsy is a safe and effective technique for evaluation of spinal lesions; however, the accuracy of the preoperative biopsy findings has been disappointing. Although all treatments are valid, no one has been demonstrated to be better. Our proposed treatment, a corpectomy and fixation with a titanium mesh cage filled with allograft bone and an anterior cervical plate, showed good results.

Conclusions: The rarity of cervical FD and the lack of detailed reports with long-term follow-up periods complicate the research on the optimal treatment approach in these cases, but apparently all are valid for pain control. In our case, a corpectomy and fixation with a titanium mesh cage filled with allograft bone and an anterior cervical plate was carried out and showed good results. We submit this surgery option to be considered in these rare type of injuries.
\end{abstract}

Cervical Spine

Keywords: fibrous dysplasia, cervical spine, anterior arthrodesis

\section{INTRODUCTION}

Fibrous dysplasia (FD) is an uncommon benign intramedullary fibro-osseous lesion. ${ }^{1}$ The etiology of FD has been linked to an activating mutation in the gene that encodes the $\alpha$ subunit of stimulatory $G$ protein located at $20 \mathrm{q} 13.2-13.3$. $^{2}$ In FD the normal lamellar cancellous bone of medullar canal is replaced with immature fibro-osseous tissue, resulting in poorly formed trabeculae of immature woven bone, leading to its expansion, distortion, and structural weakness., ${ }^{3,4}$ This disease presents in either a monostotic (MFD) or polyostotic (PFD) form, and with or without endocrinopathy. The MFD form is the most frequent ( $70 \%$ of the cases reported). ${ }^{4}$

Typically, the FD is asymptomatic and discovered incidentally. However, some cases present with painful bone swelling or pathological fractures. ${ }^{1,3}$ Cervical spine compromise is rare with only 36 cases reported. ${ }^{1,3-30}$ Currently, the natural history of cervical FD is poorly understood, and its treatment remains controversial. ${ }^{4}$ The aim of this paper is to analyze and discuss the management of cervical FD through a case report and literature review.

\section{CASE REPORT}

A 46-year-old woman underwent cervical spine magnetic resonance imaging (MRI) for the investigation of a submandibular bultoma. MRI revealed a lytic lesion on the $\mathrm{C} 6$ right vertebral body involving the homolateral pedicle with hypo-intensity in T1 and T2, and hyperintensity in STIR that spread to soft tissues, with enhancement after intravenous contrast administration.

There was no family history of bone disease. Her medical history included history of cigarette smoking and hypothyroidism after hemithyroidectomy. On physical examination, the patient denied cervical pain, but reported occasional radiating pain down the left arm without loss of strength. She presented no abnormal pigmentation of the skin. Regular laboratory examinations including hemogram, thy- 
roid, and hepatic function tests were normal. Serum calcium, inorganic phosphate, bone alkaline phosphatase, parathyroid hormone, and 25-hydroxyvitamin D were also normal.

Computed tomography (CT) scans of the cervical spine showed an expansive lytic lesion that affected the $2 / 3$ of the C 6 vertebral body and a discontinuity of the upper vertebral plate, compatible with a fracture, and alterations in bone trabeculation. Similar lesions were found in L5, S1, and S2. No other body lesions were detected by full body CT scan. The patient underwent a CT-guided percutaneous needle biopsy that revealed no signs of malignancy; however, no etiological diagnosis was obtained. With the results of the biopsy, FD was suspected, but other bone tumors and vertebral infection were also considered. Based on the radiologic findings, the lesions were thought to be PFD of the cervical spine.

The decision to proceed with surgery in this case was made based on the presence of C6 radiculopathy, and the risk of vertebral body collapse. According to Weinstein, Boriani, Biagini (WBB) stage, the lesion was considered as stage 3 benign tumor involving $\mathrm{A}-\mathrm{C}$ layers and 6-9 zones extension (A-C; 6-9). Following WBB criteria, a wide excision was considered. An anterior cervical approach was performed, exposing C6 vertebral body. Subsequently, a biopsy and C6 corpectomy were carried out. The bone involved was easily removed with curettage and rongeurs. Vertebral reconstruction was performed with insertion of anterior titanium mesh cage (Moss-Miami System; De Puy Spine, Warsaw, Indiana) with allograft bone. Fixation plate and screws at C5-C7 (Sonoma Anterior Cervical Plate, Sea Spine, San Diego, California) were used for additional internal fixation. There were no perioperative complications. Histopathologic examination showed fibrous tissue within medullary bone and irregularly shaped bony trabeculae embedded in the fibrous stroma, consistent with FD. At the end of follow-up, 2 years after surgery, the patient progressed favorably without clinical or radiological recurrence. The L5-S2 lesion remained painless and there were no signs of vertebral collapse.

\section{DISCUSSION}

FD represents $2.5 \%$ of all bone neoplasms and $7 \%$ of benign bone neoplasms. ${ }^{31}$ MFD is more frequent $(70 \%)$ than PFD $(27 \%)$ or McCune-
Albright (3\%). ${ }^{1}$ FD affects children and young adults with equal sex distribution; only in McCuneAlbright syndrome is there a female preponderance. $^{3}$ Although any skeletal bone may be affected, cervical spine affection is rare. ${ }^{32}$ The aim of this study was to analyze and discuss the management of cervical FD through a new case report of polyostotic cervical FD and literature review on this matter. We conducted a systematic review of the available literature using various search strategies. The following databases were searched: MEDLINE, Scopus, PubMed, and Cochrane systematic reviews, using the terms "Fibrous Dysplasia," "cervical tumors," and "vertebral tumors." Two authors (NJH and G-TP) completed the search separately, and the results were compared twice by each. The inclusion criteria were papers written in English and cases with sufficient epidemiologic data to be studied.

Since its first description, only 37 cases including ours have been reported to date, as summarized in Tables 1 and 2. ${ }^{1,3-30}$ There have been 22 cases of MFD (62\%) and 14 cases of PFD (38\%). All cervical spine levels were affected by the disease, especially C2 (16/36 cases). Sixty-seven percent of the patients reported were men; only in 2 studies the patient's sex was not indicated. Most patients were young adults with age between 11 and 61 years old. In most patients, the most common symptom was cervicalgia (16/36 cases) in some cases initiated after trauma. Neurological involvement happened only in 10 cases. It should be noted that information regarding gender, age, trauma, and symptoms was not always reported. Of 14 cases of PFD, 8 (57\%) were men and $6(43 \%)$ were women and they had a mean age of 37.6 years old (SD $+/-13)$. Our case was a PFD case, a woman 46 years old, with an incidental diagnosis and similar properties as those published.

As in our case, the patients reported were studied by simple radiography. Expansive and lytic types were the most common radiological patterns. ${ }^{3,4,26}$ Our patient also underwent a CT scan and a MRI. $\mathrm{CT}$ is the best diagnostic tool to demonstrate the radiographic features of dysplasia., ${ }^{1,24} \mathrm{CT}$ can confirm the reduction of lamellar cancellous bone and cortical thinning, as well as collapse of the vertebrae (Figure 1). ${ }^{28,32}$ In our patient, FD was associated with a solid component of soft tissue, with contrast enhancement. MRI is thought to be a sensitive tool to demonstrate the extent of tumor 
Table 1. Details of reported cases of fibrous dysplasia (FD) of the cervical spine.

\begin{tabular}{|c|c|c|c|c|c|c|c|}
\hline Study & Sex & Age, $\mathbf{y}$ & Presentation & Type of FD & Location & Treatment & Outcome (mo) \\
\hline Schlumberger et $\mathrm{al}^{7}$ & M & 20 & Posttraumatic & Monostotic & C4 (Body) & Biopsy/observation & NM \\
\hline $\begin{array}{l}\text { Rosendahl-Jensen } \\
\quad \text { et al }\end{array}$ & $\mathrm{F}$ & 35 & Posttraumatic & Monostotic & $\begin{array}{l}\text { C4 (body, lateral } \\
\text { mass, posterior } \\
\text { elements) }\end{array}$ & $\begin{array}{l}\text { Curettage and } \\
\text { bone graft }\end{array}$ & Asymptomatic (12) \\
\hline Resnik et $\mathrm{al}^{9}$ & $\mathrm{~F}$ & 27 & Posttraumatic & Monostotic & $\begin{array}{c}\text { C6 (body, lateral } \\
\text { mass, lamina) }\end{array}$ & Biopsy/observation & $\mathrm{NM}$ \\
\hline Stompro et $\mathrm{al}^{10}$ & $\mathrm{M}$ & 26 & Neck pain & Polyostotic & $\mathrm{C} 2$ & Biopsy/observation & Asymptomatic (10) \\
\hline \multirow[t]{2}{*}{ Wright et $\mathrm{al}^{11}$} & NR & NR & NM & Monostotic & C2 (spinous process) & NM & NM \\
\hline & NR & NR & NM & Monostotic & C5 (Lamina) & NM & NM \\
\hline Stirrat et al ${ }^{12}$ & M & 25 & Neck pain & Monostotic & C2 (body, odontoid) & Occiput-C4, P & Asymptomatic (24) \\
\hline Smith et $\mathrm{al}^{13}$ & $\mathrm{~F}$ & 47 & $\begin{array}{l}\text { Neck pain and } \\
\text { radiculopathy }\end{array}$ & Polyostotic & $\mathrm{C} 3-\mathrm{C} 7$ & Decompression & Death $(11)$ \\
\hline $\mathrm{Hu}$ et $\mathrm{al}^{14}$ & $\mathrm{M}$ & 41 & Neck pain & Monostotic & $\mathrm{C} 2$ & $\mathrm{C} 1-\mathrm{C} 3, \mathrm{P}$ & Asymptomatic (29) \\
\hline Ohki et $\mathrm{al}^{15}$ & $\mathrm{~F}$ & 20 & Mass & Monostotic & C2 (spinous process) & $\begin{array}{c}\text { Curettage and } \\
\text { bone graft }\end{array}$ & Asymptomatic (60) \\
\hline Nishiura et al ${ }^{16}$ & M & 37 & Myelopathy & Polyostotic & $\mathrm{C} 1-\mathrm{C} 2$ & Curettage, $\mathrm{A}$ and $\mathrm{P}$ & $\begin{array}{l}\text { Bone graft resorption } \\
\text { (NM) }\end{array}$ \\
\hline Villas et $\mathrm{al}^{17}$ & $\mathrm{M}$ & 11 & Painful torticollis & Monostotic & $\begin{array}{l}\text { C4 (body, L lateral } \\
\text { mass) }\end{array}$ & $\begin{array}{l}\text { Complete removal, } \\
\mathrm{A} \text { and } \mathrm{P}\end{array}$ & Asymptomatic (48) \\
\hline Ehara et $\mathrm{al}^{18}$ & $\mathrm{M}$ & 19 & Incidental finding & Monostotic & Cl (lateral mass) & NM & NM \\
\hline Janus et al $^{19}$ & M & 12 & Neck pain & Polyostotic & $\mathrm{C} 2, \mathrm{C} 5, \mathrm{C} 6, \mathrm{~L} 1$ & Biopsy/observation & Neck pain $(\mathrm{NM})$ \\
\hline Mezzadri et $\mathrm{al}^{3}$ & $\mathrm{~F}$ & 35 & $\begin{array}{l}\text { Neck pain and } \\
\text { radiculopathy }\end{array}$ & Polyostotic & $\mathrm{C} 3, \mathrm{C} 5$ & Corpectomy, A & Asymptomatic (36) \\
\hline Perlick et $\mathrm{al}^{20}$ & $\mathrm{~F}$ & 53 & Myelopathy & Polyostotic & $\mathrm{C} 1-\mathrm{C} 3$ & $\mathrm{P}$ & Asymptomatic (48) \\
\hline Marshman et al ${ }^{21}$ & $\mathrm{M}$ & 35 & Pathologic fracture & Monostotic & $\begin{array}{l}\mathrm{C} 3 \text { (body, R lateral } \\
\text { mass) }\end{array}$ & $\begin{array}{l}\text { Corpectomy with } \\
\text { instrumented } \\
\text { fusion }\end{array}$ & Asymptomatic (18) \\
\hline Dickerman et $\mathrm{al}^{22}$ & $\mathrm{M}$ & 35 & Myelopathy & Polyostotic & $\mathrm{C} 1, \mathrm{C} 2$ & $\mathrm{P}$ & NM \\
\hline Dang et $\mathrm{al}^{23}$ & M & 35 & $\begin{array}{l}\text { Neck pain and } \\
\text { myelopathy }\end{array}$ & Polyostotic & $\mathrm{C} 2, \mathrm{C} 3, \mathrm{C} 6$ & VP & Asymptomatic (12) \\
\hline Medow et $\mathrm{al}^{24}$ & $\mathrm{~F}$ & 40 & Neck pain & Polyostotic & $\mathrm{C} 2, \mathrm{C} 3, \mathrm{C} 5$ & Excision, $\mathrm{P}$ & Asymptomatic (25) \\
\hline Proschek et $\mathrm{al}^{5}$ & $\mathrm{M}$ & 56 & Neck pain & Monostotic & $\begin{array}{l}\text { C4 (body, posterior } \\
\text { elements) }\end{array}$ & Biopsy/observation & Neck pain (6) \\
\hline Sambasivan et $\mathrm{al}^{25}$ & $\mathrm{M}$ & 35 & $\begin{array}{l}\text { Neck pain and } \\
\text { radiculopathy }\end{array}$ & Monostotic & $\begin{array}{l}\mathrm{C} 4 \text { (posterior } \\
\text { elements) }\end{array}$ & Laminectomy & $\mathrm{NM}$ \\
\hline  & M & 55 & Headache & Monostotic & $\begin{array}{l}\mathrm{C} 2 \text { (posterior } \\
\text { elements) }\end{array}$ & Laminectomy & NM \\
\hline Arantes et $\mathrm{al}^{26}$ & $\mathrm{~F}$ & 53 & Neck pain & Monostotic & C1 (R lateral mass) & $\begin{array}{l}\text { Laminectomy with } \\
\text { curettage }\end{array}$ & Asymptomatic (48) \\
\hline \multirow[t]{2}{*}{ Schoenfeld et $\mathrm{al}^{28}$} & $\mathrm{M}$ & 39 & Incidental finding & Monostotic & $\begin{array}{l}\text { C7 (body, spinous } \\
\text { process) }\end{array}$ & Biopsy/observation & Asymptomatic (36) \\
\hline & $\mathrm{M}$ & 19 & Neck pain & Monostotic & C1 (lateral mass) & Biopsy/observation & Asymptomatic (24) \\
\hline Kotil et $\mathrm{al}^{29}$ & $\mathrm{M}$ & 55 & $\begin{array}{l}\text { Neck pain and } \\
\text { myelopathy }\end{array}$ & Monostotic & C2 (All) & $\begin{array}{l}\text { Curettage and } \\
\text { cemented }\end{array}$ & $\mathrm{NM}$ \\
\hline Bangash et $\mathrm{al}^{30}$ & $\mathrm{M}$ & 16 & Headache & Monostotic & $\mathrm{C} 1$ & Laminectomy, $\mathrm{P}$ & Asymptomatic (18) \\
\hline Lee et $\mathrm{al}^{1}$ & $\mathrm{M}$ & 61 & $\begin{array}{l}\text { Neck pain and } \\
\text { radiculopathy }\end{array}$ & Polyostotic & $\mathrm{C} 2, \mathrm{C} 4$ & Excision, C3-C5, A & Asymptomatic (8) \\
\hline \multirow[t]{6}{*}{$\mathrm{Wu}$ et $\mathrm{al}^{4}$} & M & 37 & Neck pain & Monostotic & $\mathrm{C} 4$ & Excision, A y $\mathrm{P}$ & Asymptomatic (24) \\
\hline & $\mathrm{M}$ & 48 & Incidental finding & Monostotic & $\mathrm{C} 2-\mathrm{C} 3$ & Curettage, $\mathrm{P}$ & Asymptomatic (34) \\
\hline & $\mathrm{M}$ & 28 & Neck pain & Monostotic & $\mathrm{C} 2$ & Curettage, A & Asymptomatic (33) \\
\hline & $\mathrm{M}$ & 53 & Myelopathy & Polyostotic & C6-C7 & Excision, A y $\mathrm{P}$ & Asymptomatic (46) \\
\hline & $\mathrm{M}$ & 17 & $\begin{array}{l}\text { Neck pain }+ \\
\text { quadriplegia }\end{array}$ & Polyostotic & C2-C3, T6-T8, L1-L5 & Biopsy/observation & Asymptomatic (42) \\
\hline & $\mathrm{F}$ & 38 & $\begin{array}{c}\text { Back pain and } \\
\text { myelopathy }\end{array}$ & Polyostotic & C4-C6, T1-T12 & $\begin{array}{l}\text { Decompression, VP } \\
\text { and } \mathrm{P}\end{array}$ & Asymptomatic (24) \\
\hline Zhong et $\mathrm{al}^{6}$ & $\mathrm{~F}$ & 38 & $\begin{array}{r}\text { Neck pain }+ \\
\text { Paraplegia }\end{array}$ & Polyostotic & C7-T1 & Refused surgery & NM \\
\hline
\end{tabular}

Abbreviations: A, anterior fusion; C, cervical; F, female; M, male; NM, not mentioned; P, posterior fusion; VP, vertebroplasty.

involvement, assess neural compression, and to establish differential diagnoses. ${ }^{4,24,32}$ FD appears as a hypointense homogeneous lesion in T1, except for pathological fractures. ${ }^{21}$ In $\mathrm{T} 2$, the lesion is heterogeneous depending on the amount of fibrous tissue, bone tissue, cellularity, cystic alterations, hemorrhage, and cartilaginous tissue. ${ }^{1,21,28}$ Administration of intravenous gadolinium produces a homogeneous lesion enhancement, like in our patient. $^{21}$ Although we suspected cervical FD in our patient, a differential diagnosis was carried out. The differential diagnosis of FD includes hemangi- 
Table 2. Summary of reported cases of fibrous dysplasia of the cervical spine.

\begin{tabular}{|c|c|c|}
\hline & Cases & Percentage \\
\hline \multicolumn{3}{|l|}{ Type } \\
\hline MFD & 22 & $62 \%$ \\
\hline PFD & 14 & $38 \%$ \\
\hline \multicolumn{3}{|l|}{ Sex } \\
\hline Male & 24 & $67 \%$ \\
\hline Female & 10 & $28 \%$ \\
\hline NM & 2 & $5 \%$ \\
\hline \multicolumn{3}{|l|}{ Age, y } \\
\hline Range & \multicolumn{2}{|c|}{$11-61$} \\
\hline Median & \multicolumn{2}{|r|}{35} \\
\hline Mean & \multicolumn{2}{|r|}{35} \\
\hline \multicolumn{3}{|l|}{ Location } \\
\hline $\mathrm{C} 1$ & $7 / 36$ & $19 \%$ \\
\hline $\mathrm{C} 2$ & $16 / 36$ & $44 \%$ \\
\hline $\mathrm{C} 3$ & $8 / 36$ & $22 \%$ \\
\hline $\mathrm{C} 4$ & $9 / 36$ & $25 \%$ \\
\hline $\mathrm{C} 5$ & $6 / 36$ & $17 \%$ \\
\hline C6 & $6 / 36$ & $17 \%$ \\
\hline $\mathrm{C} 7$ & $4 / 36$ & $11 \%$ \\
\hline \multicolumn{3}{|l|}{ Presentation } \\
\hline Posttraumatic & 3 & $8 \%$ \\
\hline Neck pain & 11 & $32 \%$ \\
\hline Neck pain and radiculopathy & 4 & $11 \%$ \\
\hline Myelopathy & 7 & $20 \%$ \\
\hline Neck pain and plegia & 2 & $5 \%$ \\
\hline Incidental finding & 3 & $8 \%$ \\
\hline Others symptoms & 4 & $11 \%$ \\
\hline NM & 2 & $5 \%$ \\
\hline \multicolumn{3}{|l|}{ Treatment } \\
\hline Biopsy and observation & 8 & $22 \%$ \\
\hline Decompression & 1 & $3 \%$ \\
\hline Vertebroplasty & 2 & $5 \%$ \\
\hline Curettage and grafting & 7 & $20 \%$ \\
\hline Complete excision with or without fusion & 14 & $39 \%$ \\
\hline NM & 4 & $11 \%$ \\
\hline \multicolumn{3}{|l|}{ Outcome } \\
\hline Asymptomatic & 22 & $61 \%$ \\
\hline Neck pain & 3 & $9 \%$ \\
\hline Death & 1 & $2 \%$ \\
\hline NM & 10 & $28 \%$ \\
\hline
\end{tabular}

Abbreviations: MFD, monostotic fibrous dysplasia; PFD, polystotic fibrous dysplasia; NM, not mentioned.

omas, giant cell tumor, bone aneurismal cysts, Paget's disease, and osteoblastomas. In older patients, multiple myeloma or metastases should also be considered. ${ }^{1,21,32}$

We performed a CT-guided percutaneous biopsy that ruled out malignancy, but failed to provide an etiological diagnosis. CT-guided percutaneous biopsy is a safe and effective technique for evaluation of spinal lesions, and the reported global diagnostic accuracy is approximately $90 \%{ }^{4,33}$ However, the accuracy of the preoperative biopsy findings in FD series has been disappointing. ${ }^{4}$ A possible factor that could explain the low diagnostic accuracy of FD may be its benign nature. Biopsies of benign tumors have an accuracy rate lower than that of malignant lesions. It could also be because FD is composed of different parts, including lytic, sclera,

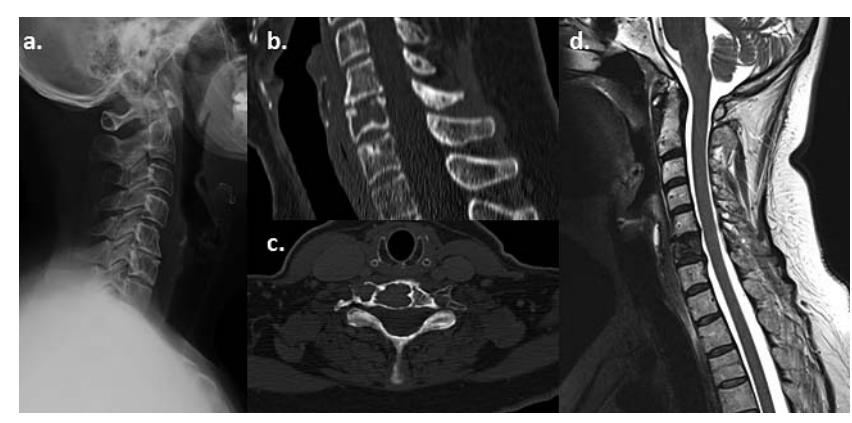

Figure 1. Preoperative imagings of our patient with cervical fibrous dysplasia. (a) Lateral cervical x-ray. (b, c) Sagittal and axial section of computed tomography showing an osteolytic image with a sclerotic margin in the C6 vertebral body and a superior vertebral disc discontinuity compatible with a fracture. (d) Sagittal section of magnetic resonance imaging shows a lytic lesion at 66 with hypointense sign in $\mathrm{T} 2$.

and soft tissue parts. To obtain a precise result, a representative specimen must be obtained with all components, especially in sclerotic lesions. ${ }^{34,35}$ As recommended by the literature, an open biopsy was carried out on suspicion of vertebral FD. ${ }^{4,21,32}$ In our patient, open biopsy and treatment were performed at the same time. Due to the risk of vertebral collapse, surgery was the treatment of choice in our case. The role of surgical treatment for FD is still controversial. ${ }^{23}$ In most cases of FD involving the nonaxial skeleton, conservative treatment is recommended, even after pathological fractures. The curative potential for all fracture sites has been reported to be $94 \%{ }^{35}$ Conservative treatment, particularly with PFD, has also been recommended in vertebral FD. ${ }^{36}$ Although, because of the low incidence of cervical spine FD and the scarcity of detailed reports with long-term followup, it is difficult to compare the effectiveness of the different treatment approaches. ${ }^{1,3-30}$ Moreover, some reports did not report the type of treatment of choice neither the follow-up period. ${ }^{6,11,18}$ The mean follow-up period of the 32 cases that did report the treatment's outcome was 28 months, ${ }^{1,3-30}$ with the exception of 1 case with a 20 -year follow-up period. ${ }^{32}$ In our case, our follow-up was 24 months, at the end of this period our patient progressed favorably without clinical or radiological recurrence.

Nowadays, surgical treatment is indicated for persistent pain, neurological deficits, vertebral collapse, instability and/or cord compression. ${ }^{1,3-5,7-17,19-30,32}$ For these reasons, we decided to operate only on the C6 lesion and not on the L5S2 lesions. Surgical goals in the present case were as follows: pathological diagnosis, removal of the 


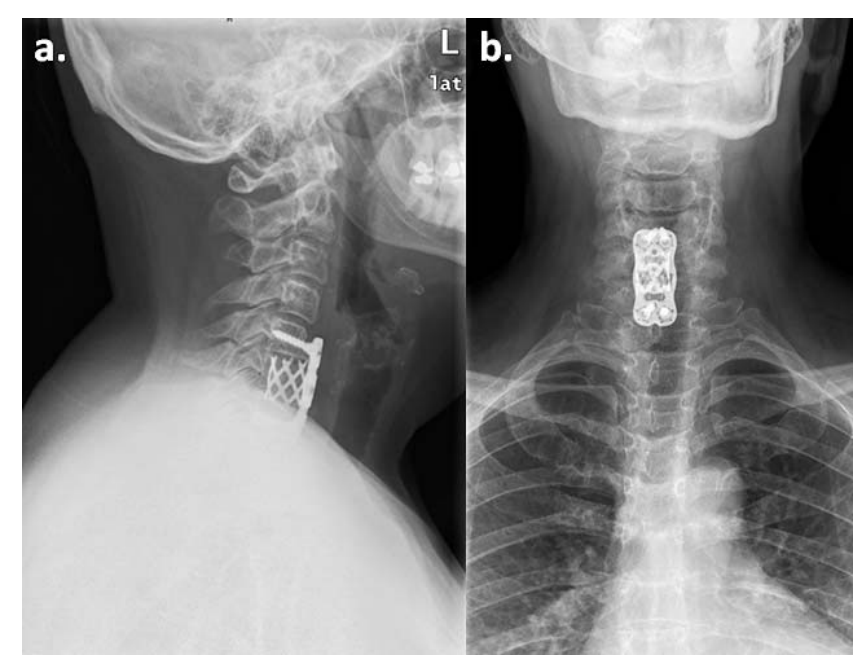

Figure 2. Postoperative imagings of our patient with cervical fibrous dysplasia. (a, b) Lateral and anterior-posterior cervical x-ray showing fixation with a titanium mesh cage with allograft bone at C6 level and an arthrodesis C5-C7 with ad anterior cervical plate.

lesion, and stabilization of the spine. In our patient, a biopsy, an anterior C6 corpectomy, and fixation with a titanium mesh cage filled with allograft bone and plate C5-7 was carried out. In our case, anterior instrumentation was sufficient; however, in the cases reported, surgical approaches varied. The anterior approach was used in cases in which, like in our case, the vertebral body was involved. ${ }^{1,3-5,7,9,28}$ Posterior decompression was performed when vertebral involvement was complete and when there was no clear anterior compression. . $^{8,10-12,14,15,17-27,29,30}$ A combined surgical approach, anterior and posterior, was used in only 5 cases. $4,13,16,17$

Like in our patient, and regardless of the therapeutic intervention, almost all surgically treated patients, as summarized in Table 2, demonstrated good outcomes, even those cases with demonstrated invasion of the graft by FD. ${ }^{16}$ In 8 of the studies in which the type of treatment was reported, the diagnosis was confirmed by biopsy and no additional treatment was instituted..$^{4,5,7,9,19,28}$ In 1 case, only a decompression was performed. ${ }^{13}$ In 2 cases a vertebroplasty was done., ${ }^{4,23}$ Seven cases were managed with curettage and grafting ${ }^{4,8,12,14-16}$ and 14 cases were managed with complete excision with or without fusion on the basis of the resulting degree of spinal instability. ${ }^{1,3,4,17,20-22,24-27,29,30}$ Only 1 major complication has been reported: 1 patient who underwent combined anterior-posterior surgery developed a complete quadriplegia 4 hours postsurgery, and died eventually after 11 days. ${ }^{13}$

\section{CONCLUSIONS}

FD has an approximately equal percentage of women/men, especially in PFD, and young patients (mean age of 37.6 years old [SD \pm 13$]$ ). Clinical presentation is usually casual or only clinical pain. CT-guided percutaneous biopsy is a safe and effective technique for evaluation of spinal lesions; however, the accuracy of the preoperative biopsy findings in FD series has been disappointing. The rarity of cervical FD and the lack of detailed reports with long-term follow-up periods complicate the research on the optimal treatment approach in these cases, but apparently all are valid for pain control. In our case, a corpectomy and fixation with a titanium mesh cage filled with allograft bone and an anterior cervical plate was carried out and showed good results.

\section{ACKNOWLEDGMENTS}

All procedures performed in studies involving human participants were in accordance with the ethical standards of the institutional and/or national research committee and with the 1964 Declaration of Helsinki and its later amendments or comparable ethical standards.

Informed consent was obtained from the participant included in the study.

\section{REFERENCES}

1. Lee SH, Han IH, Kang DW, Choi BK. Cervical fibrous dysplasia presenting as a pathologic fracture in an older patient. J Korean Neurosurg Soc. 2011;50(2):139-142.

2. Weinstein LS, Chen M, Liu J. Gs(alpha) mutations and imprinting defects in human disease. Ann N Y Acad Sci. 2002;968:173-197.

3. Mezzadri JJ, Acotto CG, Mautalen C, Basso A. Surgical treatment of cervical spine fibrous dysplasia: technical case report and review. Neurosurgery. 1999;44(6):1342-1346.

4. Wu FL, Jiang L, Liu C, et al. Fibrous dysplasia of the mobile spine. Spine (Phila Pa 1976). 2013;38(23):2016-2022.

5. Proschek D, Orler R, Stauffer E, Heini P. Monostotic fibrous dysplasia of the spine: report of a case involving a cervical vertebra. Arch Orthop Trauma Surg. 2007;127(2):75-79.

6. Zhong H, Liu J, Wang Y. Monostotic fibrous dysplasia of cervical spine. Jt Bone Spine. 2015;82(1):65.

7. Schlumberger HG. Fibrous dysplasia of single bones (monostotic fibrous dysplasia). Mil Surg. 1946;99(5):504-527.

8. Rosendahl-Jensen S. Fibrous dysplasia of the vertebral column. Acta Chir Scand. 1956;111(6):490-494.

9. Resnik CS, Lininger JR. Monostotic fibrous dysplasia of the cervical spine: case report. Radiology. 1984;151(1):49-50.

10. Stompro BE, Alksne JF, Press GA. Diagnosis and treatment of an odontoid fracture in a patient with polyostotic 
fibrous dysplasia: case report. Neurosurgery. 1989;24(6):905909.

11. Wright JFC, Stoker DJ. Fibrous dysplasia of the spine. Clin Radiol. 1988;39(5):523-527.

12. Stirrat AN, Fyfe IS, Fisher CJ. Fibrous dysplasia of the axis. A case report. Spine (Phila Pa 1976). 1989;14(2):243-245.

13. Smith MD, Bohlman HH, Gideonse N. Fibrous dysplasia of the cervical spine: a fatal complication of treatment. A case report. J Bone Joint Surg Am. 1990;72(8):1254-1258.

14. Hu SS, Healey JH, Huvos AG. Fibrous dysplasia of the second cervical vertebra. A case report. J Bone Joint Surg Am. 1990;72(5):781-783.

15. Ohki I. Monostotic fibrous dysplasia in the spine. $J$ West Pacif Orthop Assoc. 1990;27:107-110.

16. Nishiura I, Koyama T, Takayama S. Fibrous dysplasia of the cervical spine with atlanto-axial dislocation. Neurochirurgia (Stuttg). 1992;35(4):123-126.

17. Villas C, Martinez-Peric R. Monostotic fibrous dysplasia of a cervical vertebra. Eur Spine J. 1992;1(2):137-139.

18. Ehara S, Kattapuram SV, Rosenberg AE. Fibrous dysplasia of the spine. Spine (Phila Pa 1976). 1992;17(8):977999.

19. Janus GJ, Engelbert RH, Pruijs JE. Instrumentation for correction and fixation of scoliosis in fibrous dysplasia of the thoracolumbar spine. Eur Spine J. 1998;7(3):260-262.

20. Perlick L, Rolf V, Wallny T, Schmitt O. Atlanto-axial instability presenting a rare complication in fibrous dysplasia - a case report. Unfallchirurg. 2000;103(1):73-75.

21. Marshman LA, David KM, O'Donovan DG, Chawda SJ. Fibrous dysplasia of the cervical spine presenting as a pathological fracture. Br J Neurosurg. 2004;18(5):527-533.

22. Dickerman RD. Severe fibrous dysplasia of the craniovertebral junction with transient quadriparesis: a complicated case. Br J Neurosurg. 2005;19(6):495.

23. Dang D, Baig MN, Christoforidis G, Chiocca EA, Gabriel J. C2/C3 pathologic fractures from polyostotic fibrous dysplasia of the cervical spine treated with percutaneous vertebroplasty. Eur Spine J. 2007;16(Suppl 3):250-254.

24. Medow JE, Agrawal BM, Resnick DK. Polyostotic fibrous dysplasia of the cervical spine: case report and review of the literature. Spine (Phila Pa 1976). 2007;7(6):712-715.

25. Sambasivan M, Sanalkumar P, Mahesh S, Nair KR, Basheer A. Monostotic fibrous dysplasia of the C4 cervical spine. Neurol India. 2008;56(4):497-498.

26. Arantes M, Vaz AR, Honavar M. Fibrous dysplasia of the first cervical vertebra. Spine (Phila Pa 1976). 2008;33(24):933-935.

27. Iwasaki M, Hida K, Yano S, Iwasaki Y. Case of cervical monostotic fibrous dysplasia with a large cyst. No Shinkei Geka. 2008;36(5):429-433.

28. Schoenfeld AJ, Koplin SA, Garcia R, et al. Monostotic fibrous dysplasia of the spine: a report of seven cases. $J$ Bone Joint Surg Am. 2010;92(4):984-988.

29. Kotil K, Ozyuvaci E. Fibrous dysplasia in axis treated with vertebroplasty. J Craniovertebr Junction Spine. 2010;1(2):118-121.

30. Bangash MH, Bokhary RY, Alomar SA, Baeesa SS. Fibrous dysplasia of the atlas. Neurosciences (Riyadh). 2011;16(1):76-77.

31. Fitzpatrick KA, Taljanovic MS, Speer DP, et al. Imaging findings of fibrous dysplasia with histopathologic and intraoperative correlation. AJR Am J Roentgenol. 2004;182(6):13891398.

32. Meredith DS, Healey JH. Twenty-year follow-up of monostotic fibrous dysplasia of the second cervical vertebra a case report and review of the literature. J Bone Joint Surg Am. 2011;93(13):e74.

33. Lis E, Bilsky MH, Pisinski L, et al. Percutaneous CTguided biopsy of osseous lesion of the spine in patients with known or suspected malignancy. Am $J$ Neuroradiol. 2004;25:1583-1588.

34. Altuntas AO, Slavin J, Smith PJ, et al. Accuracy of computed tomography guided core needle biopsy of musculoskeletal tumors. ANZ J Surg. 2005;75:187-191.

35. DiCaprio MR, Enneking WF. Fibrous dysplasia. Pathophysiology, evaluation, and treatment. J Bone Joint Surg Am. 2005;87:1848-1864.

36. Leet AI, Chebli C, Kushner H, et al. Fracture incidence in polyostotic fibrous dysplasia and the McCune-Albright syndrome. J Bone Miner Res. 2004;19:571-577.

Disclosures and COI: The authors report no conflict of interest concerning the materials or methods used in this study or the findings specified in this paper.

Corresponding Author: Jorge H. Nuñez, Department of Orthopedic Surgery and Traumatology, University Hospital of Vall d'Hebron, Passeig de la Vall d'Hebron, 119-129, 08035 Barcelona, Spain. Phone: +34 6004044 06; Email: m.ramirez@ vhebron.net or hassan2803med@gmail.com.

Published 21 December 2018

This manuscript is generously published free of charge by ISASS, the International Society for the Advancement of Spine Surgery. Copyright (c) 2018 ISASS. To see more or order reprints or permissions, see http://ijssurgery.com. 